\section{Analysis of Genetic Diversity in Buffalograss Determined by Random Amplified Polymorphic DNA Markers}

\author{
Xiaobo Zhang, Derong Su${ }^{1}$, and Luyi Ma \\ The Key Laboratory of Silviculture and Conservation of Ministry of \\ Education, College of Resources \& Environment, Beijing Forestry \\ University, Beijing, 100083, China
}

\author{
Yan Zhao \\ College of Resources \& Environment, Shanxi Agricultural University, \\ Shanxi, 030801, China
}

Additional index words. Buchloe dactyloides, PCR, low-maintenance lawns, drought resistance

\begin{abstract}
Buffalograss [Buchloe dactyloides (Nutt.) Engelm.] is a warm-season grass for low-maintenance lawns. The objective of our study was to assess the genetic variation in 10 accessions of buffalograss obtained from the Chinese Academy of Agricultural Sciences by random amplified polymorphic DNA (RAPD) markers. Fourteen of the 60 primers screened generated 72 highly repeatable polymorphic bands. A dendrogram constructed on the basis of the unweighted pair group method arithmetic average clustering algorithm revealed that nine of 10 accessions formed two distinct clusters. Genetic similarity coefficients calculated from the RAPD data ranged from 0.30 to 0.89 with the lowest value of 0.30 measured between No. 4 and No. 7 from Japan and the United States, respectively. The highest value of 0.89 was measured between No. 6 and No. 8 from the United States and Mexico, respectively. The cophenetic correlation coefficient ( $r$ ) was 0.92 , indicative of a very good fit between the data matrix and the resulting cluster analysis. Principal coordinate analysis (PCO) clearly grouped nine accessions on the two axes with a single accession from the United States that did not cluster with others. The PCO clustering pattern corresponded well with the dendrogram. No. 7 from the United States did not cluster with any other accessions either in the dendrogram or on the basis of the PCO.
\end{abstract}

Buffalograss, native to the short-grass prairie region of North America, is a lowmaintenance, warm-season turfgrass with excellent drought and heat resistance (Beetle, 1950). With water becoming a limited resource and environmental issues of greater concern to the public, there is increased interest in the use of more resource-efficient turf such as buffalograss. The most recent breeding work has been for low-water use landscapes where buffalograss maintains better turfgrass quality than many cool-season grasses (Riordan et al., 1993)

Genetic variation is the basis for breeding programs; therefore, it is important to identify genetically distinct plants for breeding purposes. Because morphologic characteristics are often influenced by environmental factors, parental selection should be based on genetic information that is reliable and consistent. This information will be a valuable tool in support of the genetic improvement of this species in the future. Molecular markers

\footnotetext{
Received for publication 30 Nov. 2006. Accepted for publication 14 Feb. 2007.

This research was supported by the National Natural Science Foundation of China (No. 50679002).

${ }^{1}$ To whom reprint requests should be addressed; e-mail angiaoo@gmail.com
}

are widely used to determine genetic diversity (Brummer et al., 1995), create genetic maps, conduct linkage analyses of quantitative and qualitative traits (Grattapagalia and Sederoff, 1994), and determine phylogenetic relationships (Perez de la Vega, 1993). The random amplified polymorphic DNA (RAPD) marker analysis (Williams et al., 1990), based on a polymerase chain reaction (PCR) with arbitrary primers, is not influenced by the environment and is used effectively for analyzing genetic diversity in various grasses, including grain amaranths (Amaranthus spp.) (Transue et al., 1994), switchgrass (Panicum virgatum L.) (Gunter et al., 1996), creeping bentgrass (Agrostis stolonifera L.) (Casler et al., 2003; Golembiewski et al., 1997), and Kentucky bluegrass (Poa pratensis L.) (Johnson et al., 2002).

Genetic diversity assessments among these buffalograss accessions will provide useful information for local and international researchers to more effectively use this species. In this study, RAPD markers were used to study genetic variation in buffalograss obtained from the Chinese Academy of Agricultural Sciences (CAAS) to assess its genetic diversity. Our primary goal was to analyze the genetic relationships among these 10 buffalograss accessions and cultivars by using RAPD markers and provide genetic information for future breeding programs.

\section{Materials and Methods}

Plant material and DNA isolation. Plant samples in this study were obtained from CAAS. Our analysis was performed on 10 accessions (Table 1). Genomic DNA was extracted from fresh leaves by using the improved hexadecyltrimethyl ammonium bromide (CTAB) extraction procedure (Murray and Thompson, 1980). Fresh leaves were ground to fine powder in liquid nitrogen and transferred to a $2-\mathrm{mL}$ tube containing $0.5 \mathrm{~mL}$ of preheated $\left(65^{\circ} \mathrm{C}\right) 2 \times \mathrm{CTAB}$ extraction buffer [100 mM Tris-HCl, pH 8.0, $1.4 \mathrm{M} \mathrm{NaCl}$, $20 \mathrm{~mm}$ ethylenediaminetetraacetic acid (EDTA), 2\% (w/v) CTAB]. A $0.5 \mathrm{~mL}$ of 24 chloroform: 1 isoamyl alcohol (by volume) was added in equal volume and inverted vigorously for $7 \mathrm{~min}$ followed by a $10-\mathrm{min}$ centrifuge at maximum $(15,000 \mathrm{~g})$. The aqueous phase was transferred to a new tube containing $0.4 \mathrm{~mL}$ of ice cold isopropanol and inverted gently to form a clump. The clump was then transferred to a new tube containing $0.5 \mathrm{~mL}$ CTAB wash solution [76\% (v/v) ethanol, $0.2 \mathrm{~m}$ sodium acetate, $\mathrm{pH}$ 5.2] and incubated on ice for $20 \mathrm{~min}$. The supernatant was poured off and the pellet was washed again with the same CTAB wash solution followed by centrifuge for $1 \mathrm{~min}$. The supernatant was removed and the pellet was allowed to dry 3 to $5 \mathrm{~min}$ before a $50 \mu \mathrm{L}$ TE was added with $1 \mu \mathrm{L}$ of $10 \mathrm{mg} / \mathrm{mL}$ RNase and was incubated at $37^{\circ} \mathrm{C}$ for $30 \mathrm{~min}$. Fifty microliters of $7.5 \mathrm{M}$ ammonium acetate and $0.25 \mathrm{~mL} 100 \%$ ethanol were added to the solution and inverted gently followed by centrifuge at maximum $(15,000 \mathrm{~g})$ for $5 \mathrm{~min}$. The supernatant was removed and the remaining pellet was washed with $0.25 \mathrm{~mL}$ $75 \%$ ethanol followed by brief centrifuge for $1 \mathrm{~min}$. The supernatant was removed and the pellet was dried for $15 \mathrm{~min}$ and dissolved in $50 \mu \mathrm{L}$ TE. DNA was extracted from 18 individual plants for each of four randomly selected accessions (No. 2, No. 3, No. 5, and No. 8) described previously for analysis genetic variation within accession. The quantity and quality of extracted DNA were determined both by spectrophotometric analysis and gel electrophoresis.

Random amplified polymorphic DNA reaction system. Amplification reactions were performed on the basis of the protocol of Williams et al. (1990) with modifications. DNA samples were adjusted to $50 \mathrm{ng} / \mu \mathrm{L}$ and used in the amplification reactions with a final volume of $25 \mu \mathrm{L}$ containing $2 \mu \mathrm{L}$ of 50 ng/ $\mu \mathrm{L}$ DNA template, $1 \mu \mathrm{L}$ of $50 \mathrm{mM} \mathrm{MgCl}_{2}$, $2 \mu \mathrm{L}$ of $2.5 \mathrm{~mm}$ dNTP, $0.5 \mu \mathrm{L}$ of 1.0 unit Taq DNA polymerase, $0.4 \mu \mathrm{L}$ of a random primer (Sangon Biotech., Shanghai, China), $2.5 \mu \mathrm{L}$ of $10 \times$ PCR buffer $(200 \mathrm{~mm}$ Tris-HCl, 500 $\mathrm{mm} \mathrm{KCl}, \mathrm{pH} 8.0$ ), and $16.6 \mu \mathrm{L}$ of distilled, deionized water resulting in a $25-\mu \mathrm{L}$ solution.

Polymerase chain reaction was carried out using a Biometra Personal Thermal Cycler (Biocompare Ltd., Foster City, Calif.) 
Table 1. Detail of materials used in the present study for RAPD-based genetic diversity analysis.

\begin{tabular}{llll}
\hline No./RAPD number & \multicolumn{1}{c}{ Sex form } & Country & Origin \\
\hline 1 & Female & USA & Vegetative \\
2 & Female & USA & Vegetative \\
3 & Female & Canada & Vegetative \\
4 & Male & Japan & Vegetative \\
5 & Female & USA & Vegetative \\
6 & Female & USA & Vegetative \\
7 & Male and female & USA & Seeded \\
8 & Female & Mexico & Vegetative \\
9 & Male & Australia & Vegetative \\
10 & Male & Mexico & Vegetative \\
\hline
\end{tabular}

${ }^{\mathrm{z}}$ The numbers were used for identifying accessions in the genetic similarity analysis (Table 2). RAPD $=$ random amplified polymorphic DNA. program for $60 \mathrm{~min}$ at $37{ }^{\circ} \mathrm{C}$ for prior digestion of the DNA template and then the thermal cycler for $3 \mathrm{~min}$ at $94{ }^{\circ} \mathrm{C}$ for initial DNA denaturation, followed by 45 cycles of $1 \mathrm{~min}$ at $94{ }^{\circ} \mathrm{C}, 45 \mathrm{~s}$ at $36{ }^{\circ} \mathrm{C}$, and $1 \mathrm{~min}$ at $72{ }^{\circ} \mathrm{C}$. The last cycle was followed by a 10 -min extension at $72{ }^{\circ} \mathrm{C}$. The samples were then stored at $4{ }^{\circ} \mathrm{C}$ until electrophoresis. Amplified products were resolved in $1.2 \%$ $(\mathrm{w} / \mathrm{v})$ agarose gels in $1 \times$ TAE $(40 \mathrm{~mm}$ Trisacetate, 1 mм EDTA pH 8.0) buffer. A 200-bp DNA ladder was used as a molecular weight size marker for each gel at $120 \mathrm{~V}$ for $1.5 \mathrm{~h}$ and stained with ethidium bromide. The RAPD profiles were visualized and photographed under an ultraviolet light imaging system (HuaYan Technologies, Ltd., Jiangsu, China).

Primer screening. The analyses were performed by using only good-quality and repeatable amplified bands. Sixty decamer oligonucleotide primers (S-series, 1-60) from Sangon Biotech. were screened for polymorphism DNA bands among the individuals of four randomly selected accessions. Fourteen primers were selected for RAPD analysis on the basis of their high levels of polymorphism obtained from the randomly selected samples and were used to analyze all accessions of Buchloe dactyloides.

Data collection and statistical analysis. For the statistical analysis, the patterns at all RAPD loci were scored for each polymorphic band as 1 for band presence and 0 for band absence. These scores were entered into a binary rectangular matrix on the subprogram NTedit of NTSYSpc v.2.10e program (Exeter Software, Setauket, N.Y.) (Rohlf, 2000). The data were analyzed with module SIMQUAL to generate genetic similarity coefficients among all possible pairs and ordered in a similarity matrix on the basis of Jaccard's coefficients (Jaccard, 1908). The similarity matrix was run on module SAHN (sequential, agglomerative, hierarchical, and nested) (Sneath and Sokal, 1973) by using the unweighted pair group method with arithmetic average (UPGMA) clustering algorithm (Sokal and Michener, 1958) to generate a dendrogram. The module MXCOMP of the NTSYSpc v.2.10e was used to calculate a cophenetic correlation between the similarity matrix and original matrix to measure goodness of fit (Lapointe and Legendre, 1992).

Principal coordinate analysis (PCO) was conducted by using module DCENTER and
EIGEN of NTSYSpc (Gower, 1996). This multivariate approach was chosen to complement the cluster analysis information; because cluster analysis is more sensitive to closely related individuals, the PCO is more informative regarding distances among major groups (Hauser and Crovello, 1982).

Analysis of molecular variance (AMOVA; Excoffier et al., 1992) was performed on 72 individual plants sampled from four randomly selected accessions to calculate the variation within and among accessions using the RAPD polymorphic loci. The data were generated using the ARLEQUIN v.3.01 software (Excoffier et al., 2005). The total variance was partitioned into variance among accessions and variance among individuals within accessions.

\section{Results and Discussion}

Random amplified polymorphic DNA polymorphisms. Genetic variation of some major turfgrass species such as perennial ryegrass (Lolium perenne L.) (Sweeny and Danneberger, 1997), Blue grama (Bouteloua gracilis H.B.K. Lag. ex Steud.) (Phan et al., 2003), and velvet bentgrass (Agrostis canina L.) (Hollman et al., 2005) has been studied by using RAPD markers. In this study, we used RAPD markers to assess the genetic variation among 10 accessions of buffalograss assembled from the CAAS collections. Fourteen of the 60 primers screened were selected for DNA amplification reactions because they gained many highly repeatable polymorphic bands. Of 129 bands, 72 (55.8\%) were polymorphic and were scored for analysis in a binary matrix by the subprogram NTedit of NTSYSpc program. On average, in this study, we detected 5.1 polymorphic bands per primer with the most (seven bands) obtained from primers S09, S28, and S47, the least (one bands) obtained from primer S53. None of the RAPD markers was specific to a particular accession.

Variation among accessions. The high level of polymorphism corresponded to a high degree of genetic variation among these buffalograss accessions. Jaccard's similarity coefficients ranged from 0.30 to 0.89 (Table 2). Because we observed no similarity coefficients value close to 1.0 between any two accessions, there were no likely redundant accessions among those sampled in our study. The highest similarity coefficient (0.89) was measured between accession No. 6 from the United States and No. 8 from Mexico. Accession No. 6 from the United States is a cultivar named ' 315 ', a female plant with dwarf growth habit and high turfgrass quality in the northern and transition zones of the United States (Riordan et al., 1995). This relationship was supported by results from the cluster analysis, in which these two accessions were members of cluster B (Fig. 1).

From the analysis of Jaccard's similarity coefficients, accession No. 4 from Japan and accession No. 7 from the United States have the lowest similarity coefficient $(0.30)$. The accession No. 7 from the United States contributes to the lowest genetic similarity between this accession and accession No. 4 from Japan. The lowest genetic similarity between No. 4 and No. 7 may be the result of a lack of genetic exchange or the highly different environmental conditions existing among these countries. Morphologically, accession No. 7 from the United States has dark green color shiny leaves with straight tips and purple stems; accession No. 4 from Japan has small and light green leaves that curled at their tips and whitish green stems.

A dendrogram (Fig. 1) was constructed by using UPGMA method cluster analysis on the basis of Jaccard's coefficients with one possible tie found between the closest pairs. The dendrogram divided nine of 10 accessions into two clusters, except accession No. 7, which did not group with the others. Cluster A was divided into a subgroup and accession No. 10. Cluster B was divided into two subgroups and accession No. 9, the first subgroup of cluster B, consists of three accessions:
Table 2. Genetic similarity matrix between 10 buffalograss accessions with RAPD markers based on Jaccard's coefficients.

\begin{tabular}{ccccccccccr}
\hline RAPD number $^{2}$ & 1 & 2 & 3 & 4 & 5 & 6 & 7 & 8 & 9 & 10 \\
\hline 1 & 1.00 & & & & & & & & & \\
2 & 0.63 & 1.00 & & & & & & & & \\
3 & 0.86 & 0.66 & 1.00 & & & & & & & \\
4 & 0.80 & 0.59 & 0.79 & 1.00 & & & & & & \\
5 & 0.60 & 0.81 & 0.63 & 0.58 & 1.00 & & & & & \\
6 & 0.78 & 0.73 & 0.77 & 0.83 & 0.71 & 1.00 & & & & \\
7 & 0.53 & 0.60 & 0.32 & 0.30 & 0.37 & 0.34 & 1.00 & & & \\
8 & 0.65 & 0.78 & 0.75 & 0.71 & 0.60 & 0.89 & 0.43 & 1.00 & & \\
9 & 0.73 & 0.64 & 0.81 & 0.70 & 0.68 & 0.61 & 0.36 & 0.68 & 1.00 & \\
10 & 0.71 & 0.76 & 0.62 & 0.55 & 0.73 & 0.65 & 0.40 & 0.57 & 0.60 & 1.00 \\
\hline
\end{tabular}

${ }^{\mathrm{z}}$ See Table 1 for the identification of accessions-cultivars.

$\mathrm{RAPD}=$ random amplified polymorphic DNA. 
No. 1, No. 3, and No. 4. The second subgroup consists of two accessions: No. 8 and No. 6 .

An ultrametric cophenetic value matrix was computed from the coefficients of SAHN cluster analysis of the similarity matrix. The cophenetic correlation coefficient between the cophenetic matrix and the RAPD data matrix was 0.92 . It could be considered a very good fit and shows that the original matrix was well represented by cluster analysis (Smouse et al., 1986).

To affirm genetic relationships among 10 buffalograss accessions revealed by cluster analysis, PCO (Fig. 2) was generated from the module DCENTER and EIGEN of the program NTSYSpc v.2.10e. PCO clearly separated the nine accessions, but the remaining one accession, No. 7 from the United States, did not group with any other accession. These results corresponded well with the cluster analysis obtained through UPGMA and confirmed the distinctness of accession No. 7.

Of the two clusters displayed in Figure 1, subgroup 2 of cluster B includes accessions whose geographic origins were closely related to the clustering pattern. For example, accession No. 6 from the United States clustered with No. 8 from Mexico with the highest similarity coefficient $(0.89)$. Similarly, accessions No. 3 from Canada and No. 1 from the United States of subgroup 1 were collected from nearby regions is consistent with the results from PCO in which these two accessions are close to each other.

From cluster A of the dendrogram, with two accessions from the United States: No. 2 and No. 5, also included No. 10 from Mexico, is consistent with the results from principal coordinate analysis in which these three accessions are close to each other. Our results suggest that accession No.10 from Mexico might have some common origin with the two accessions from the United States.

Contrary to expectations, the five accessions of buffalograss received from the United States (Table 1) did not form a single cluster. Their pairwise similarity coefficients ranged from 0.34 to 0.81 , similar to the diverse range of values exhibited among all 10 accessions. Because these accessions did not form a single cluster and displayed a wide range of variation, either these accessions exhibit a high degree of variability or possibly some of these accessions have been incorrectly identified.

Variation within accession. Results from AMOVA (Table 3) indicated that the withinaccession variation accounted for $76.9 \%$ of the total genetic variation and betweenaccession variation accounted for the remaining $23.1 \%$. These results were not surprising because Buchloe dactyloides usually is an allogamous species. Allogamous plants generally have a higher variation within accession, whereas autogamous species have relatively lower percentages of within-accession variation (43\% for Hordeum spontaneum K. Koch) (Dawson et al., 1993). The variation level observed in this study is consistent with several other

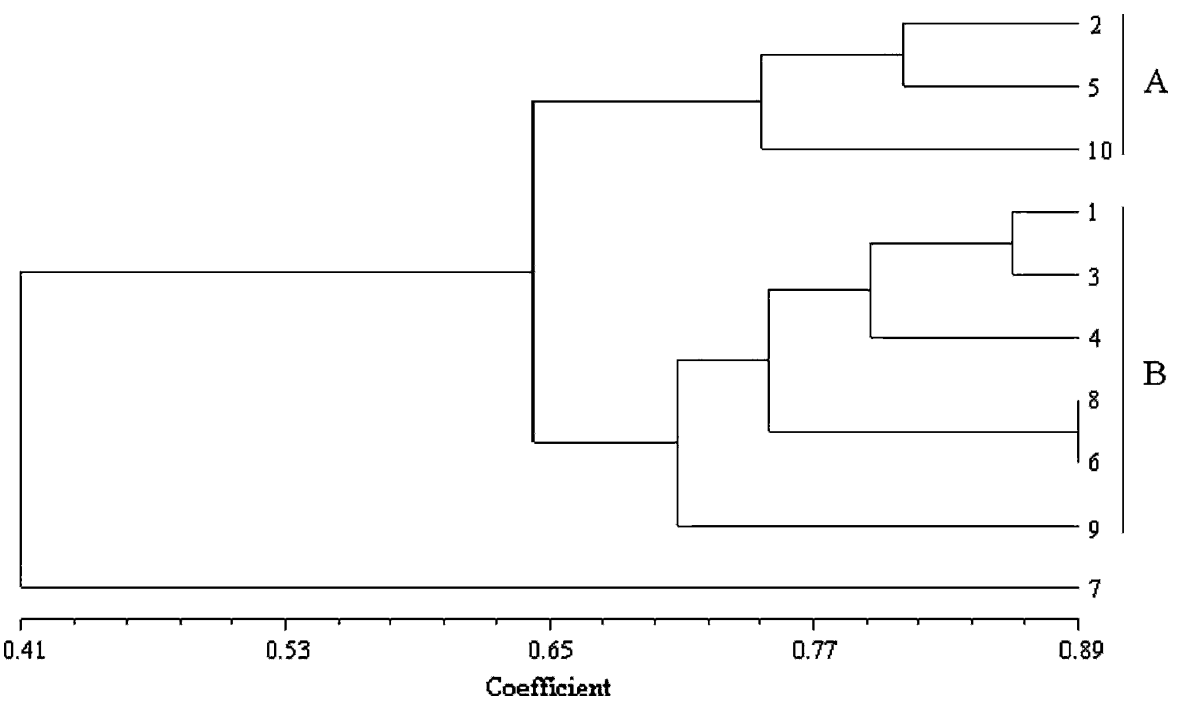

Fig. 1. Dendrogram with unweighted pair group method with arithmetic average (UPGMA) of 10 accessions of buffalograss based on the random amplified polymorphic DNA data. The dendrogram was constructed from the Jaccard's similarity coefficients matrix (Table 2).

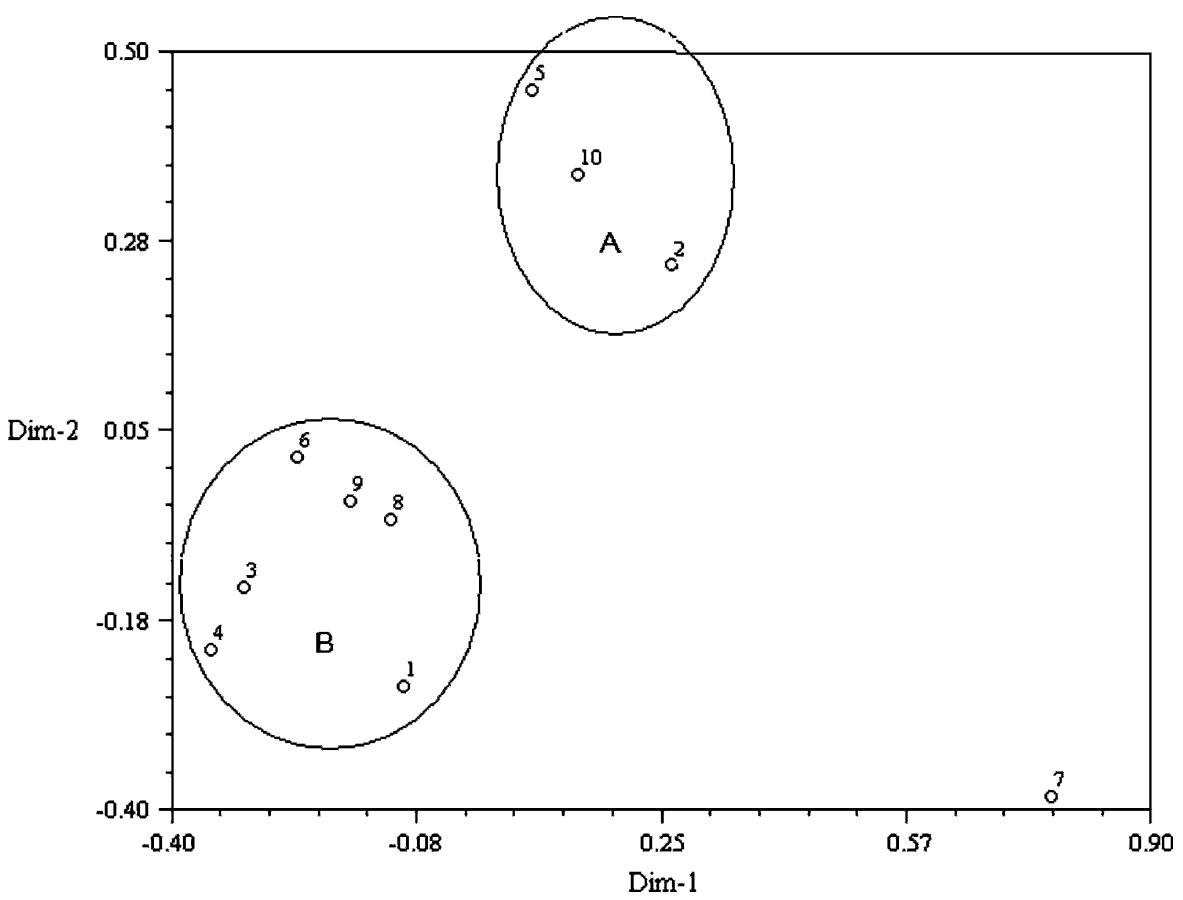

Fig. 2. Principal coordinate analysis of 10 buffalograss accessions revealed by using the Jaccard's similarity coefficients based on the random amplified polymorphic DNA data (see Table 1 for accessions and cultivars identification).

Table 3. Molecular variance analysis (AMOVA) from 72 individual plants of four randomly selected accessions based on RAPD markers.

\begin{tabular}{lccccc}
\hline $\begin{array}{l}\text { Source of } \\
\text { variation }\end{array}$ & $\begin{array}{c}\text { Degree of } \\
\text { freedom }\end{array}$ & $\begin{array}{c}\text { Sum of } \\
\text { squares }\end{array}$ & $\begin{array}{c}\text { Variance } \\
\text { components }\end{array}$ & $\begin{array}{c}\text { Percentage of } \\
\text { variation }\end{array}$ & $P$ value \\
\hline Among accessions & 3 & 362.99 & 1.34 & 23.1 & $<0.001$ \\
Within accession & 151 & 669.17 & 4.46 & 76.9 & $<0.001$ \\
\hline
\end{tabular}

$\mathrm{RAPD}=$ random amplified polymorphic DNA.

allogamous species such as crested wheatgrass (Agropyron spp. Gaertn) (Mellish et al., 2002), perennial ryegrass (Lolium perenne L.) (Huff, 1997), and meadow bromegrass (Bromus riparius R.) (Ferdinandez et al., 2001).
This article reveals important information about genetic diversity of 10 buffalograss accessions assembled. Our data suggest that RAPD markers are suitable for assessing genetic variation within and among accessions of buffalograss germplasm. Information on 
genetic relationships revealed through this study should be useful for selection of parents for future breeding or genetic studies. Future studies that include more accessions and varieties and that compare genetic relationships with morphologic characteristics can help develop a greater understanding of this species.

\section{Literature Cited}

Beetle, A.A. 1950. Buffalograss native of the shortgrass plains. Agr. Expt. Sta, Univ. of WY. Laramie. Bul. 293:1-31.

Brummer, E.C., J.H. Bouton, and G. Kochert. 1995. Analysis of annual Medicago species using RAPD markers. Genome 38:365-367.

Casler, M.D., Y. Rangel, J.C. Stier, and G. Jung. 2003. RAPD marker diversity among creeping bentgrass clones. Crop Sci. 43:688-693.

Dawson, I.K., K.J. Chalmers, R. Waugh, and W. Powell. 1993. Detection and analysis of genetic variation in Hordeum spontaneum populations from Israel using RAPD markers. Mol. Ecol. 2:151-159.

Excoffier, L., G. Laval, and S. Schneider. 2005. Arlequin Ver. 3.0: An integrated software package for population genetics data analysis. Evolutionary Bioinformatics Online 1:47-50.

Excoffier, L., P.E. Samuse, and J.M. Quattro. 1992. Analysis of molecular variance inferred from metric distances among DNA haplotypes: Application to human mitochondrial DNA restriction data. Genetics 131:479-491.

Ferdinandez, Y.S.N., D.J. Somers, and B.E. Coulman. 2001. Estimating the genetic relationship of hybrid bromegrass to smooth bromegrass and meadow bromegrass using RAPD markers. Plant Breed. 120:149-153.

Golembiewski, R.C., R.K. Dannenber, and P.M. Sweeney. 1997. Potential of RAPD markers for use in the identification of creeping bentgrass cultivars. Crop Sci. 37:212-214.
Gower, J.C. 1996. Some properties of latent root and vector methods used in multivariate analysis. Biometrika 53:325-338.

Grattapagalia, D. and R. Sederoff. 1994. Genetic linkage maps of Eucalyptus grandis and Eucalyptus urophylla using a pseudo testcross: Mapping strategy and RAPD markers. Genetics 137:1121-1137.

Gunter, L.E., G.A. Tuskan, and S.D. Wullschleger. 1996. Diversity among accessions of switchgrass based on RAPD markers. Crop Sci. 36: 1017-1022.

Hauser, L.A. and T.J. Crovello. 1982. Numerical analysis of genetic relationships in Thelypodieae (Brassicaceae). Syst. Bot. 7:249-268.

Hollman, A.B., J.C. Stier, M.D. Casler, G. Jung, and L.A. Brilman. 2005. Identification of Putative velvet bentgrass clones using RAPD markers. Crop Sci. 45:923-930.

Huff, D.R. 1997. RAPD characterization of heterogeneous perennial ryegrass cultivars. Crop Sci. 37:557-564.

Jaccard, P. 1908. Nouvelles recherches sur la distribution florale. Soc. Vaud. Sci. Nat. Bul. 44:223-270.

Johnson, R.C., W.J. Johnson, C.T. Golob, M.C. Nelson, and R.J. Soreng. 2002. Characterization of the USDA Poa pratensis collection using RAPD markers and agronomic descriptors. Genet. Resour. Crop Evol. 49:349-361.

Lapointe, F.J. and P. Legendre. 1992. Statistical significance of the matrix correlation coefficient for comparing independent phylogenetic trees. Syst. Biol. 41:378-384.

Mellish, A., B. Coulman, and Y. Ferdinandez. 2002. Genetic relationships among selected crested wheatgrass cultivars and species determined on the basis of AFLP markers. Crop Sci. 42:1662-1668.

Murray, M.G. and W.F. Thompson. 1980. Rapid isolation of high molecular weight plant DNA. Nucleic Acids Res. 8:4321-4325.
Perez de la Vega, M. 1993. Biochemical characterization of populations. In: M.D. Hayward, N.O. Bosemarka and I. Romagosa (eds). Plant breeding. Principles and prospects. Chapman and Hall, London.

Phan, A.T., Y.B. Fu, and S.R. Smith. 2003. RAPD Variations in selected and unselected blue grama populations. Crop Sci. 43:1852-1857.

Riordan, T.P., S.A. Shazer, J.M. Johnson-Cicalese, F.P. Baxendale, M.C. Engleke, R.E. Gaussoin, G.L. Horst, and R.C. Shearman. 1995. Registration of ' 315 ' buffalograss. Crop Sci. 35: 1206.

Riordan, T.P., S.A. Shazer, J.M. Johnson-Cicalese, and R.C. Shearman. 1993. An overview of breeding and development of buffalograss. Int. Turfgrass Soc. Res. 7:816-822.

Rohlf, F.J. 2000. NTSYS-pc Numerical taxonomy and multivariate analysis system. Version 2.10 manual. Applied Biostatistics, Inc., N.Y.

Smouse, P.E., J.C. Long, and R.R. Sokal. 1986. Multiple regression and correlation extensions of the Mantel test of matrix correspondence. Syst. Zool. 35:627-632.

Sneath, P.H.A. and R.R. Sokal. 1973. Numerical taxonomy. Freeman, San Francisco.

Sokal, R. and C. Michener. 1958. A statistical method for evaluating statistical relationships. Kans. Univ. Sci. Bul. 38:1409-1438.

Sweeny, P.M. and T.K. Danneberger. 1997. RAPD markers from perennial ryegrass DNA extracted from seeds. HortScience 32:12121215.

Transue, D.K., D.J. Fairbanks, L.R. Robison, and W.R. Andersen. 1994. Species identification by RAPD analysis of grain amaranth genetic resources. Crop Sci. 34:1385-1389.

Williams, J.G.K., A.R. Kubelik, K.J. Kivak, J.A. Rafalski, and S.V. Tingey. 1990. DNA polymorphisms amplified by arbitrary primers are useful as genetic markers. Nucleic Acids Res. 18:6531-6535. 